\title{
University in the role of an innovative enterprise for green economy establishment
}

\author{
Aleksandra Kobicheva ${ }^{1, *}$ \\ ${ }^{1}$ Peter the Great St. Petersburg Polytechnic University, 195251, St. Petersburg, Russia
}

\begin{abstract}
The main goal of the green economy is to establish a sustainable economy that uses natural resources efficiently and has a lower environmental impact. Many countries nowadays consider green economy as a key accomplishment in their strategic goals. Universities as a key actor in the national innovation system can contribute to this area due to elaborated innovative ideas and technologies. The aim of this paper is to prove university as an innovative enterprise that is able to be a driver in green economy establishment.
\end{abstract}

\section{Introduction}

Building a knowledge and high-tech economy is becoming the main reference point for the innovative development of the Russian Federation. The spheres of higher education and science, at the same time, are considered as key elements of the modern economy, the vector of innovative and technological development of which is the creation of a national innovation system, including an integrated research and development system with higher education, capable of flexibly adapting to the needs of the real economy [1]. According to the Concept of long-term socio-economic development of Russia, this direction is strategic and must be implemented at the federal and regional levels.

Universities responsible for the creation, storage, dissemination of new knowledge and acting as a driver for the effective development of the national innovation system are gradually becoming integrated economic entities that perform the functions of an innovation corporation and have a similar organizational structure. In this regard, this fact requires a detailed study and addition of the conceptual apparatus of the term "university"[2].

It seems expedient to compare a university with an innovation corporation. To do this, you need to understand what each organization is, what functions it performs and what structure it has.

An innovation corporation is "an association of technologically related manufacturing enterprises, various scientific centers, design and innovation organizations that carry out innovative activities" ... [3].

There are various approaches to the interpretation of the concept of "innovation". In textbooks on innovation management, innovation activity is considered as an activity aimed at using and commercializing the results of research and development to expand and update

${ }^{*}$ Corresponding author: kobicheva92@gmail.com 
the range and improve the quality of products (goods, services), improve their manufacturing technology with subsequent implementation and effective implementation on internal and foreign markets [4]. According to other sources, these are activities to organize and implement the innovation process; the use of the results of completed scientific research, experimental design developments or other scientific and technical achievements to create a new or improved product sold on the market, a new or improved technological process used in practical activities, their dissemination, as well as additional scientific research related to this, development and development work [5].

Using the realities of modern times, innovation is understood as a complex of scientific, technological, organizational, financial and commercial activities aimed at commercializing the accumulated knowledge, technologies and equipment [6]. According to the modern lawmaking interpretation, innovation activity is understood as activity aimed at transforming the results of intellectual activity in the form of inventions, utility models, industrial designs, selection achievements, topologies of integrated circuits, databases, know-how, computer programs, results of research and development and R\&D in goods (works, services), and their subsequent sale directly or as part of manufactured products (goods, works, services).

\section{Methods}

To define the concept of a university at the present stage of development, it is necessary to analyze its essence, functions and organizational structure.

Speaking about the essence of the university at the present stage, first of all, it is necessary to define its socio-economic role and mission in society. The historically changing missions of the university are best reflected in three concepts of the university university 1.0., University 2.0. and University 3.0., which were analyzed.

To determine the main functionality of modern universities, we analyzed the missions of universities from different parts of the world, which predetermine the most significant goals and objectives set by the university leadership and reflect, respectively, the functions performed by modern universities.

Also, we examined the organizational structure of a modern university, Peter the Great St. Petersburg Polytechnic university.

\section{Results}

University 1.0 - educational institutions that train specialists for professional activities in certain sectors of the economy and social sphere. The main mission is education;

University 2.0 - educational institutions in which research work and research and development play an important role. The main mission - education, is joined by a new function - conducting scientific research for the industrial sector.

The current stage of development requires universities to contribute more actively to the development of the knowledge-based economy through the commercialization of research results and the creation of new knowledge-intensive enterprises. These tasks are fully met by the Entrepreneurial university model or University 3.0.

The concept of "University 3.0" was developed in 1998 by Burton R. Clarke and he also introduced the term "Entrepreneurial Universities" into scientific circulation (the term "University 3.0" is often used in Russian literature). However, an unambiguous definition of this concept has not yet been developed. Most researchers are of the opinion that University 3.0 is an institution of higher education that can attract additional financial resources to support its activities, a university that uses innovative teaching methods, a 
university that establishes close interaction with the business community, where the developments of university researchers are introduced.

Statistics confirms the belonging of modern universities to the category "University 3.0." - over the past eight years, higher education institutions have significantly increased their performance and commercialization of their research and development (Fig. 1).

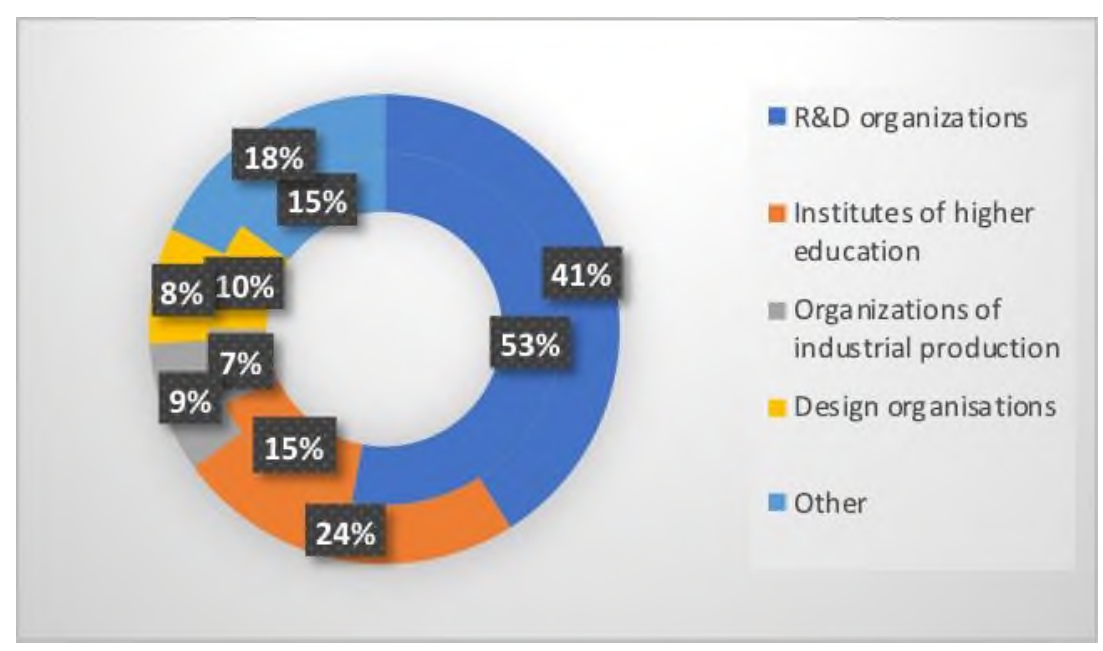

Fig. 1. Change in the proportion of organizations performing research and development (2019- outer circle, 2010 - inner circle) [7]

If until 2010 the basis of the scientific sector was made up of independent research organizations, isolated from production and education (the proportion of these organizations in the total set of organizations of the country's scientific and technical complex was more than $50 \%$ ), then after this period there have been significant changes in this area. The growth in the share of universities in the system of organizations performing research and development is primarily associated with the introduction of a system for assessing the effectiveness of a university, including indicators of research activities. So, since 2013, the state assignment of universities began to include not only services for the implementation of educational programs of higher professional education, but also scientific work. All this points to the active adaptation of universities to changing conditions during the transition to an innovative economy, as well as the growing role of universities in the country's innovative development.

Also, there is the concept of University 4.0., Which involves a complete change in the model of educational activity, in particular, an almost complete transition to distance learning through digital technologies, the use of an interdisciplinary approach and the formation of students' creative potential, research and development mainly in the field of global problems, such as overpopulation of the planet, global warming, etc., building a network and cloud organization, etc. The implementation of this concept is expected simultaneously with the transition to the concept of "Industry 4.0."

Let us also give the vision of missions by the universities themselves, both Russian and foreign (Table 1). 
Table 1. The vision of missions by universities

\begin{tabular}{|c|c|}
\hline University & Formulation of mission \\
\hline $\begin{array}{l}\text { Peter the Great St. } \\
\text { Petersburg } \\
\text { university }\end{array}$ & $\begin{array}{l}\text { The mission is to ensure its own competitiveness in the domestic } \\
\text { and foreign markets of educational services, as well as to become } \\
\text { a reliable partner of the state in building up the economic power } \\
\text { and international influence of Russia: to be a globally competitive } \\
\text { research and educational center and to become one of the world's } \\
\text { leading universities, to provide leading training of new generation } \\
\text { personnel and technological modernization of backbone industries } \\
\text { based on the use of multidisciplinary knowledge and advanced } \\
\text { supra-industry technologies. }\end{array}$ \\
\hline $\begin{array}{l}\text { Higher school of } \\
\text { Economy }\end{array}$ & $\begin{array}{l}\text { The basis of our activity is theoretical and empirical research and } \\
\text { the dissemination of knowledge. We are committed to making a } \\
\text { practical contribution to building a new Russia. }\end{array}$ \\
\hline $\begin{array}{l}\text { Siberia } \\
\text { university }\end{array}$ & $\begin{array}{l}\text { Development of intellectual capital and advanced science- } \\
\text { intensive education, ensuring a sustainable improvement in the } \\
\text { quality of life of the population of Siberia through the training of } \\
\text { highly qualified personnel capable of creative and practical } \\
\text { activities, and the generation of globally significant knowledge } \\
\text { and technologies aimed at expanding the economic potential and } \\
\text { global competitiveness of the basic sectors of the regional } \\
\text { economy }\end{array}$ \\
\hline Prinston University & $\begin{array}{l}\text { Education at Princeton is a combination of arts and sciences } \\
\text { focused on research. Although each faculty has its own } \\
\text { requirements, all students must take a certain number of liberal } \\
\text { arts courses that go beyond their narrow specialization and } \\
\text { provide universal knowledge and skills. The research priority for } \\
\text { Princeton University is very high. }\end{array}$ \\
\hline $\begin{array}{l}\text { California Institute of } \\
\text { Technology }\end{array}$ & $\begin{array}{l}\text { The mission of the California Institute of Technology is to } \\
\text { expand human knowledge and bring benefits to society through } \\
\text { the study of integrated education. }\end{array}$ \\
\hline Stanford University & $\begin{array}{l}\text { The main goal is to provide students with the qualifications } \\
\text { necessary for personal success and immediate benefit in life. } \\
\text { Other goals are to contribute to the public welfare of the first path } \\
\text { of humanity and civilization. }\end{array}$ \\
\hline
\end{tabular}

Thus, modern universities are powerful research centers specializing in a particular field of science, teaching thousands of students from different countries on the basis of the internationalization of teaching staff, the use of information and computer technologies, as well as creating and commercializing intellectual property based on the developed technologies. Let's move on to considering the organizational structure of a modern university. As an example, let's take the Peter the Great St. Petersburg Polytechnic University [8]. 


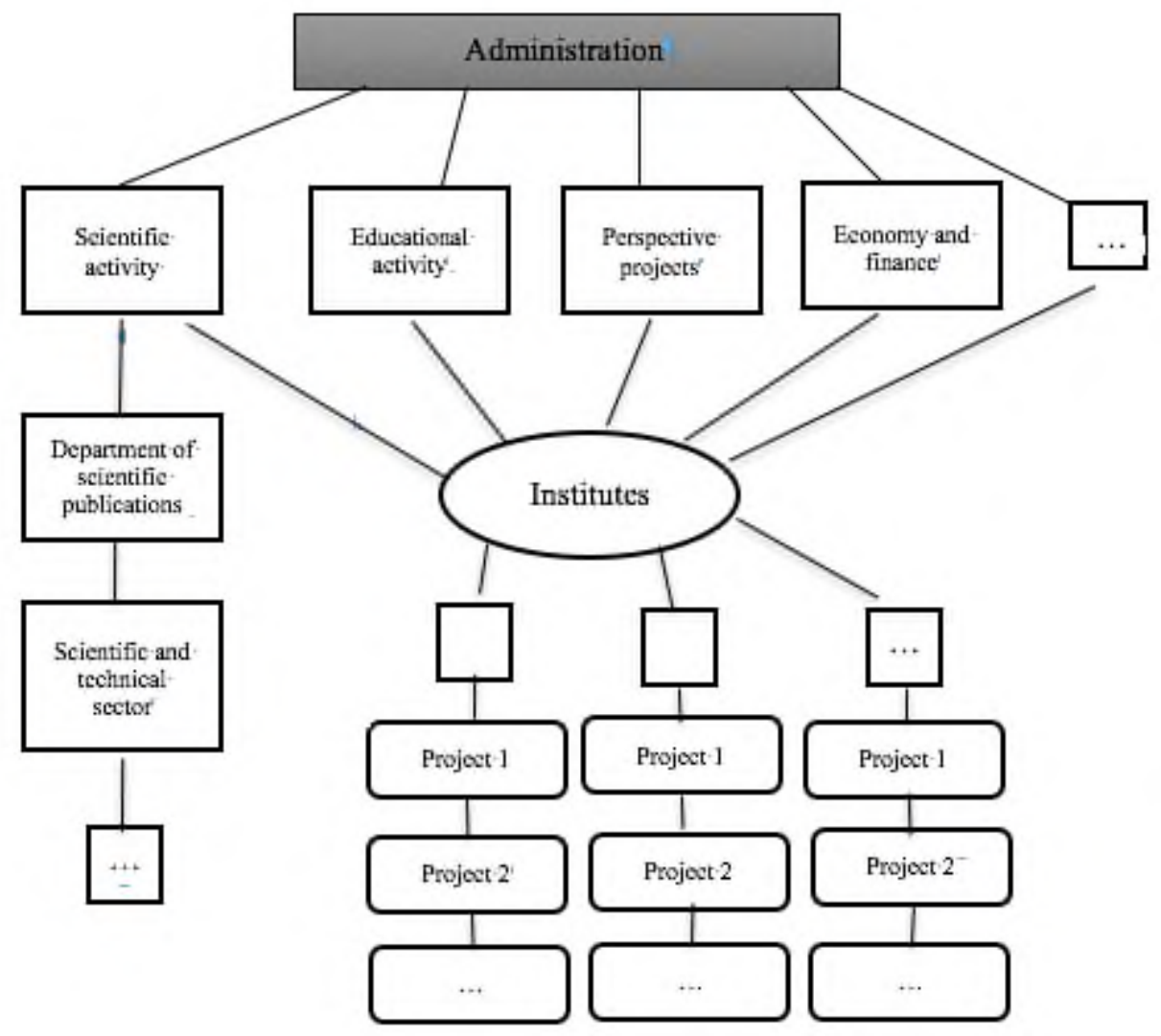

Fig. 2. Organizational structure of SPbPU

It can be seen that among the priority tasks of the university is the achievement of the goals of scientific and technical innovations. The organizational structure of the university has the properties of a functional matrix structure, it includes many units that perform creative activities to create innovations of a certain profile (depending on the institution), as well as auxiliary and management units that ensure the implementation of R\&D plans and the implementation of created innovations.

By definition, the organizational structure of an innovation corporation is a set of scientific, design, design, technological and information units (laboratories, departments, sectors, groups) that carry out the main creative activities to create innovations of a certain profile and specialization, as well as production, auxiliary and management subdivisions that ensure the implementation of thematic R\&D plans and the implementation of the created innovations..

\section{Discussion}

Thus, there is a clear similarity between a modern university and an innovative corporation, on the basis of which we propose to supplement the conceptual apparatus of a modern university.

The University of the 21 st century is a higher educational institution that equally effectively carries out educational and scientific activities based on the principles of integrating science and education, which has a similar organizational structure with 
innovative corporations and can stimulate economic progress through intensive innovation, as well as induce social changes in society. University is becoming the key player for green future by investing in this area new knowledge and technologies.

\section{Conclusions}

Every year, universities are assigned more and more responsibility for the implementation of innovative activities, including active research and development in priority areas of development, the implementation of an integration function in relation to all subjects of innovation and the creation of an innovation ecosystem. This article analyzes the essence, functions and organizational structure of a modern university. Based on the results obtained, it is concluded that it is necessary to supplement the conceptual apparatus a modern university, taking into account the expansion of all spheres of its activity and areas of responsibility.

\section{References}

1. S. K. Antipov, A. A. Bocharov, A. Kobicheva and E. E. Krasnozhenova, Assessment of Region Economic Development on the Basis of Neural Network Model. IOP Conference Series: Earth and Environmental Science, 302, 012094 (2019) DOI: $10.1088 / 1755-1315 / 302 / 1 / 012094$

2. S. Barykin, A. Kobicheva, Logistical approach to universities integration in the Russian innovation economy, MATEC Web of Conferences, 170, 01020 (2018) DOI: $10.1051 /$ matecconf $/ 201817001020$

3. E. N. Kravtsova, V. P. Voronin, Innovative activity of the enterprise. Creative economy, 3-8, 2(6) (2008)

4. I. I. Dyakov, N. A. Tretyak, K. S. Grishchenko, Assessment of the innovative environment of universities Modern Education, 22 -34, 1 (2018) DOI: 10.25136 / 2409-8736.2018.1

5. A. V. Fedorova, The development of cooperation of higher education organizations and innovative enterprises: organizational forms: the dissertation of the candidate of economic sciences. (Institute of Regional Economics Problems of the Russian Academy of Sciences, St. Petersburg, 2014)

6. S. A. Prokopenko, T. S. Selevich, Research and develop ideas about the essence of the university, Philosophy of Education 6(63) 2015

7. Russian statistical yearbook. Federal State Statistics Service Rosstat. Moscow, 2018. http://www.gks.ru/wps/wcm/conne ct / rosstatmain / rosstat / ru / statistics / publications / catalog / doc 1135087342078 (Last accessed 11.01.2021)

8. The website of Peter the Great Saint-Petersburg university. URL: https://www.spbstu.ru/structure/units/ (Last accessed 11.01.2021) 